\title{
D. H. Lawrence's Theatre: Identity and Naturalism in a Collier's Friday Night
}

\author{
By Juan Tomás Matarranz-Araque*
}

The aim of this paper is to describe the relationship between identity and naturalism in D. H. Lawrence's play A Colliers Friday Night. Lawrence's drama usually becomes a fusion of the autobiographical and the fictive, making a strenuous effort to become realistic.

The paper also deals with the play's ideological connotation, traditionally seen as a highly naturalistic private drama, lacking of interest compared to Lawrence's novels. The creative opportunities of generational, psychological or linguistic conflicts are described by Becket as 'the inevitable opposition between male and female principles that co-exist within the individual' (100); they make of the play a microcosm of the wider hegemonic normativity. The play's educational component and its depiction of economic relationships make of it an odd play. Its constraints reflect the fact that 'nothing happens, yet the continual play of love and hate, the living process of young lives being moulded by the domestic and social and economic environment and asserting themselves against the pressures, controls the movement' (Sagar 3). These pressures are often expressed physically, creating a sense of claustrophobia. The lack of dramatic climax make the audience perceive the ideological connotations when characters are forced to return to their daily routine in an environment where women become perpetuators of the hegemonic values and also victims of the, as they failed in their emancipation.

\section{Introduction}

In order to understand Lawrence's way of presenting his new conception of the individual, it is necessary 'first of all to consider the problems of context -the underlying conditions which define the functions and limits of cultural activity, including language and literature as forms of creative social practice' (Hampton 3). At the same time, we may also avoid a central authorial error: that of reading an early dramatic work in terms of the author's posthumous controversies, which become especially conspicuous in Lawrence's critical history. Therefore, many critics point out the need of remembering both Lawrence's mining background, and the idea that miners have 'an instinct for beauty of form, sound, colour and speech. No part of the community has a

*Professor, Universidad Europea de Madrid, Spain. 
keener ear and love of music than the miner... The keen love of beauty in its various forms in their reaction to their gloomy work, and too often gloomy environment' (Sagar 153).

There was a great economic, social and scientific shift in Britain in the early $20^{\text {th }}$ century. After the death of Queen Victoria, social unrest grew, causing some perturbation in political and cultural elites; it was thought that these elites were far behind in the intellectual and artistic debates going on in the rest of the continent. For many writer, the years prior to the Great War showed that art served only for evasion; we can conclude that although London was 'overrun with theatres, there was a 'pervasive intellectual apathy' behind the lack of good prose drama -or, as even the most anglophile of immigrants, Henry James, had to concede, theatre in England was a social luxury and not an artistic necessity'. (Trussler 110) Many playwrights insisted on the creation of a subsidised national theatre like in France. The abundant low quality commercial theatre ran along an incipient theatre inspired in Granville-Barker, Galsworthy or Shaw. Many authors increased the language of violence and aggression in their works. It is widely recognised, violent impulse in Lawrence was, as well as his 'misanthropy, misogyny, erotic violence and destructive impulses' (Benyon 94) existed in some of his late works. Many of his plays, written before his best-known novels incorporated both naturalistic elements and Ibsen-like feminine characters who openly talked about their needs onstage. This historical lack of political drama contrasts the real-life situation with the predominant role of the family institution. Lawrence presented these contradictions in a very original manner, maybe due to his personal background.

\section{Context}

Traditionally, Lawrence's eight full plays are grouped in three stages. The first one covers the so-called 'mining plays'. The Widowing of Mrs Lawrence was written in 1911 and published in 1914. The Daughter in Law was written in early 1913. A Collier's Friday Night in 1909. Lawrence was then living in Croydon and was working as a teacher. At some moment he probably decided to establish himself as a professional writer. Short stories like The Odour of Chrysanthemums were being published in those years. As L. R. Williams states, 'A Collier's Friday Night is a first writing version of some of the central experience of Sons and Lovers' (9). It was premiered posthumously, in 1938; it had to wait almost thirty years to be staged again by Peter Gill at the Royal Court Theatre, a few years after Lady Chatterley's trial.

The three plays follow the form of a private drama, attempting to modernise the traditional structure as far as the style and new tastes of society allowed the author. His characters also explicitly state their wishes for economic independence from their husbands, resembling 'Shaw and Barker (who) also dragged the theatre into the arena of women's issues, acknowledging that half of the population in the world had been 
disenfranchised, patronised, or bullied into submission for centuries without a voice' (The Guardian 1). Probably, Lawrence thought of that transition from Victoria's reign to King Edward's in terms of an old order which 'had been in power, in much of the same forms, for a very long time-at least for the length of the Old Queen's reign. The result of this lengthy tenure was an ossification of authority that encased and cramped the new: the forms of values had become values; institutions had become more important than the ideas they embodied' (Hynes 5).

Lawrence can use certain naturalistic aspects under a new light thanks to his direct experience in the mining world, as well as to his working class background. Most of the writes have to achieve this only through previous documentation. Lawrence realism is presented as the 'social life of the mining village as a knowable community' (Holderness 23). Moreover, his plays differ from other realistic plays in that 'rather than examining works in terms of their understanding of, say, the determining power of the economic base (...) they tend to pay attention to explaining the minutiae of a novel's topical reference' (Guy 6). Under this perspective, literary text becomes equal to the information provided in other texts and documents which are not literary. However, we have to think that even the most convinced of Marxists would recognise a certain degree of independence of the literature from the economic conditions which helped create it, so that it may be recognised that 'casual relationships demand that individual texts possess a different authority, status or value, (so) the whole process of assigning status and authority to texts is of curse exactly what new historicists try to avoid' (Guy 6). It should be remembered that technical naturalism involves the representation of a natural environment whereas dramatic naturalism uses environment as a symptom, soaking the characters' lives and making them fight against it.

In the three plays afore mentioned, Lawrence reworks his own relationship with the society of the time in some specific terms. First of all, Chothia talks of a 'conscious reworking of Burn's genial celebration of Scottish working-class life, The Cottar's Friday night' (204), incorporating working class characters. In these sense, the play's structure mirrors the idea of commercial theatre, following the division between the 'bourgeois repertoire of the West End houses -where perpetuation of the traditional typology, the working classes were still largely presented as either pert but subservient or lazy and parasitic' (Griffin 193). Secondly, Lawrence probably finds his inspiration in Hauptmann or Tolstoy. It also criticises educational issues, like the excessive number of students in class and the teachers' desire to instill 'not only some sense of discipline...but to control other undesirable habits' (Griffin 143). We should remember that Lawrence himself, like the play's main character Ernest Lambert, is a good example of the educational options opened after Balfour's 1902 Education Act, and also of the contradictory discourses between the legal system and the effective implementation of this act. This is the reason behind the first dramatic conflict with his father: having always been a miner, he refuses to accept his son's open prospect, his newly acquired linguistic 
resources and the expenses of his daily trip to the university, nor the books Ernest needs to acquire.

\section{Conflict}

Social and political incoherence appear in Lawrence's play as an attempt to question the individual set against his environment from his most elementary socialisation: family and school. The result is that, as the new social identity has been problematized in his plays, the individual often becomes detached from the community. This is especially true considering 'the miner's family in the nineteenth and early twentieth century was an economic unit' (Griffin 155). Worthen explains that the play exposes a plot within the context of the "pay night, baking-night, the night when you go out on the town if you can afford to, when (if you cannot) you envy those who can. For many people it marks the end of the working week, and the arrival of the pay-packet, but for the housewives, it simple means the continuation of the work (242). Conflict in the play starts in the domestic sphere when mothers and wives cooperate in breaking the male bounds. Women construct a different type of solidarity in the play based partially in the language of exclusion, promoting a new linguistic acquisition in her children. This special use of language becomes relevant because the play makes 'an emphasis on ways of speaking, minutely observed and reproduced, as the social reality of a particular dimension' (Williams 1993: 140). The audience might easily note that gender and generational conflict are depicted from a new perspective which needs to specify the everyday details, including not only dialectal and idiolectal characteristics, but also a whole recreation of a linguistic network of love and hate between sexes and generations. As it has been mentioned, conflict lies mainly within the marriage, but there is also class conflict, usually within a broader conflict of the use of language of tension and violence.

Becket's words about 'the creative possibilities of conflict, either within the individual or between individuals (usually between men and women)' (10) are relevant to this point. Conflict between men and women, the natural and the mechanic, even between modernity and tradition, are central in the play. Becket adds a second level, when mother and son discuss 'fiercely, pathetically, with passion' (III, 72).

A third level might be added too, when Lawrence describes how 'the great crime that moneyed classes and promoters of industry committed in the palmy Victorian days was the condemning of the workers to the ugliness, ugliness (...): meanness and formless and ugly surroundings, ugly ideals... The human soul needs actual beauty more than bread' (Moore 25). By doing it, Lawrence describing the control mechanisms that sustain dominant ideology, like the economic control of the individuals or the lack of cultural formation. This structure of oppression has its mirror in the father, who attempts to retain control of the house when saying 'I'm a master in this house, an' I'm going to be. I tell you, I'm a master of this house'. (Act III, 68) He is quite unsuccessful, 
but the most important element for Lawrence is to describe the intellectual and linguistic failure of his patriarchal incapacity. The new society, represented by Ernest, seems to be shifting to a new for, and the father's position has become residual.

\section{Naturalism}

The play is set in one room only and within the strict framework of the codes of a mining family. The play's naturalism is found in the meticulous amount of real life detail, intended to make the spectator believe that it is a slice of life drama, directly taken as a photograph from real life. Maybe Lawrence intended both to renovate the dramatic form and to raise the interest of the audience in new dialectal manners. High naturalism also becomes the tool used by Lawrence to depict the network of solidarity between men and to question social institutions; he therefore ahs to sort out the apparent contradiction between style and contend. The play's depiction of habits and manners is rooted in the fact that Lawrence was part of the linguistic and economic environment.

These manners are heavily represented with the dialect of the Midlands, inconsistently represented at times on the graphically, but which conveys the vividness of being able to choose a specific variety according to every situation. The verb 'are' changes from the 'They h'are, Gertie, they h'are' (Act I, 27) to hoare in Act III. Lawrence is often aware of the difficulty of transcribing that dialect, and expresses it in the stage directions :'his accent is becoming still more urban. His O's are a's, so that 'nothing' is 'nathing'. (69). The choice of a particular dialectal form is at times an irrational reaction of the father against an aggression: 'You're a liar. I heard the scuffle. You don't think I'm a fool, do you, woman?' (Act III, 69). In principle, the spectator may sympathise with the father's motives, despite his openly aggressive forms, and some of the minor characters echo that feeling. This idea of approaching the audience's feelings becomes relevant also when Lawrence texts show his 'drawing on his experience of home life and the life and the life of the mining community he knew so well. The plays are naturalistic and, if nothing else, show Lawrence's skill in dialogue and the rendering of dialect speech' (Becket 36). The fact is that most of the audience would be unaware that dialect might create this simultaneous ambivalent feeling of closeness and distance from the play. A good example is the alternative use of the Nottingham dialect and the Standard English in the characters of Gertie and Nellie. This becomes especially relevant when contrasted to the father's broad dialect and his aggressive language, received by the others with 'a general silence, as if the three listeners were shrugging their shoulders in contempt and anger' (Act I 24).

Moreover, there is always an ideological choice in the exposition of literary events. For example, Genette (Selden 21) establishes a list of binary oppositions which display the uselessness of conflict between reality and 
literature; that is, between description and narration. He favours the latter, and that is why Lawrence might have confused reality and his own subjectivity. One of the reasons to hold this idea is that the stage directions often seem to be aimed at the reader, not at the audience. Expressions like 'there is a persistent silence' (Act II 24) or that 'she glances supremely at Ernest, feeling him watching her' (ibid) suggest an intromission from the author-narrator difficult to represent onstage. This goes beyond a mere succession of 'detailed stage directions' (Fernihough 139) because the play identifies naturalism and everyday life experience. An example of this is the long stage direction in Act I about Mr Lawrence's physical appearance, which includes a detailed specification of every movement he makes on the stage:

He is a man of middling stature, a miner, black from the pit. His shoulders are pushed up because he is cold. He as a bushy iron grey beard...He wears a grey and a black neckerchief, and being coatless his black arms are bare to the elbow, where end the loose dirty sleeves of his flannel singlet. (Act I 23)

Even if Lawrence intended to write for middle class bourgeois audience, this text is thickly low class and rural. It also attempts to make clear the social and economic shift from the past, which possibly explains the lack of interest of Iden Payne to put it onstage, aware as he was of the majority of middle class bourgeois audience. On the other hand, the author's interest in writing a play in the mood of the School of Manchester's realistic plays is easily understood. Thus, Trussler describes:

From 1908 at the Gaiety, Miss Horniman's Manchester company worked with particular success to reflect local attitudes and concerns-which though arguably just as class ridden as those of the West End, now seem less exclusively and claustrophobically so (270271)

Payne wrote back some vague recommendations to correct the play in 1912, and as a result of such correspondence, Lawrence decided to forget about the play, never to take it up again

\section{Private Form, Public Appearance}

The play is divided into three acts and it has no scenes, although they are easily identifiable. The three Aristotelian units have been respected, reinforcing the notion of verisimilitude. The interval between acts is always short, expressed both as a stage direction like in 'The same room, half an hour later' (59) or as an inserted stage direction: (Was Maggie Pearson gone when you came? Nellie: no, she's only been gone out about three quarters of an hour' (61) 
Many critics have often compared this play to Sons and Lovers as if this was the major work and the play a mere secondary to it. Furthermore, many critics think that Lawrence's 'fortunes as a dramatist were finished by 1933, and he makes a distinction between the early and the later writing for theatre, which supports Sean O'Casey's response to Lawrence's work' (Becket 37). I believe that this statement also refers to Lawrence's lack of knowledge of the theatrical world, and to the fact that he was an outsider to that world, but not to the invalidity of his plays, neither to his lack of intention to become a playwright, at least at some point of his life. Therefore, the play not only reflects about the simple familiar tensions in different genres. The economic hardship and the crude arguments are carefully chosen to reflect the society Lawrence lived in. The first layer of social analysis focuses on personal differences, ideolectal issues or the family members. The second step deals with the social expectations for change and one's place in society, and also with labour conflict and work relations. Finally, it represents the limited ideological and hierarchical aspects found within a small part of society and its nornativised forms of thought. The play's ideological contexts tend to sustain the social and economic decay process, but it includes strong criticism on the patriarchal ways of thought and the fathers' losing control of their traditional domestic territory.

This is the ground of the father's fierce relationship with the other family members, who consider that other things matter besides the material world. In contrast, there is an explicit comradeship between the father and the other miners when they distribute the weekly pay, expressed in broad Nottingham dialect. Similarly, there is a search for the language of love from Ernest and his girlfriend. The contrast between two worlds is easily seen in the swear words between the elder couple and with the language between mother and son whey they talk 'with great gentleness, having decided not to torment him'; it is even cleared in her final recognition: 'Yes, I understand now (she bluffs him)' (Act III 73).

Lawrence attempts to level the three acts symmetrically in time and intensity. Domestic discussions are usually tempered by bringing in secondary conversations about the miners' distribution of the weekly pay or about different acquaintances. It also brings in a comic situation, like the neighbour Gertie, who includes news from the outer world to soother the reaching of the climax of the play. The result is that the conflictive family plot exceeds its limits, and depicts the characters' resistances to their economic and social conditions. Lawrence develops a complex frame of oppositions and contradictions between the characters which the audience will try to sort out outside the closed drama presented onstage. This situation is poorly managed by the father, either by claiming the traditional power of men over women, or through the use of insult. His unavoidable use of broad dialect only makes this distance with the rest of the characters bigger. The consequence is that the father's dialogue allows the audience to perceive the hostility of his family and neighbours. The distance between the father and the rest of the family is felt more strongly when the father hands the newspaper to his son but keeps silent. 
It is the mother who is in charge of the intellectual training of the children. By taking in this task, she also excludes the father's Intellectual superiority of women is reinforced by Nellie's conversation with the miner Barker:

Barker: an' ye river 'eared that piece 'The Maiden's Prayer'?

Nellie: (Turning aside and laughing) Yes. Do you like it? It s pretty, isn't it?

Barker: I 'ad that for my last piece.

Nellie: Did You? Can you play it?

(...)

Nellie: Save me, Gert, same me! I thought I was done for that time. I gave myself up! The poor piano! Moter, I'll want tuning now. (3839)

\section{Education}

Foucault (2002) has studied that any education system is a political form of keeping and modifying the adequacy of discourses with the different forms of knowledge and the power they imply. Constant throughout the play is the fight between the parents around the children's education. On the one hand, Mrs. Lambert is intellectually more active than her husband. When she wants to make her children speak with her superior accent, she says.

Mother: I don't know where an instinct for Latin comes from. Not from the Lamberts, that's a certainty. Your Aunt Ellen would say, from the Vernons (she smiles ironically as she rinses to pour him a cup of tea, taking the teapot from the hob and standing it, empty, on the father's plate)

Ernest: who are the Vernons?

Mother: (smiling) It's a wonder your Aunt Ellen or your Aunt Eunice has never told you...

(...)

Mother: A parcel of nonsense...

Ernest: Oh, go on, ma, you're tantalizing! You hug it like any blessed girl.

Mother: My great-great-grandfather married a lady Vernon-so they say (30-31)

Her accent has become more aristocratic, and her children are willing to respond to that feeling of linguistic superiority in contrast to the father. Following Worthen, 'Mrs Lambert is caught between her desire to see Ernest get his college education -to her, a passport out of the slavery of the mining village to which she herself feels condemned -and the budget problems posed by books' (242). Ernest is strongly influenced by his mother's ideas and shares with her the linguistic variety and the same educational interests, transmitted 
through the system. All this is useless for the father's ideological world view, first because of a feeling that his world view is not understood, but also because much of the father's speech is misinterpreted by the rest of the family. Within the small society that the family represents, he has been marginalized from the discourse of truth.

In the almost incestuous relationship between mother and son, and in his relation to other women, 'Lawrence familiarly juxtaposes the language of sex and death, explaining in his own terms the sexual failure, the hatred and fear of sex, which he perceives in repressive Western and specifically at this time, northern European culture' (Becket 64). In this process of focusing her attention on her children, the mother may have won a son, but has lost a husband. Compared to his sister, Ernest moves with a feeling of loss, like if all characters were under unknown pressures. The father, always associated in the play with the language of strength, anger or fear seems to answer to the same circumstances as his equivalent character in Sons and Lovers:

His crude attempt at regaining patriarchal control, and his representation often as marginal, a great deal of narrative sympathy is, in fact, set aside for him, who is, ultimately, scared of his highly strung, sharp-tongued wife. As in 'A Collier's Friday Night' however, the main focus is on the bond between mother and sons, against this stranger-father; and ultimately on the rivalry for the heart of the artist-son between the mother and the son's sweetheart'. (Becket 44)

It is widely accepted that Walter Morel and Mr. Lambert represent Lawrence's father in real life, and that Ernest and Paul are Lawrence himself; moreover, many of the episodes $\mathrm{n}$ the play mirror real-life events. Becket's conception of the loss of patriarchal control explains how the immediacy of the language, its seed and its ways of exclusion, are the tools used by Lawrence to reflect over such exclusion in his own terms.

\section{Conclusion}

Most of the characters in this private drama participate in the construction of a certain type of localism, built up around a common family, in a play where plot is almost non-existent. All characters seem to be asserting themselves against social and economic pressures, but also against the other family members. These constant pressure are expressed physically ('nerves', 'contempt', 'weary', 'anger') and they contribute to creating a claustrophobic play where the dramatic climax is full of ideological connotations. In order to try to escape the social and familiar pressures, they turn to their daily routine: cooking of the bread, studying, the weekly pay or attending the fair. It is the audience that is expected to overcome such claustrophobic environment. 
Similarly, the play does not state the author's identity problems as in later works. In any case, against T. S. Eliot's opinion that 'great poetry does not need to concern itself with any such dangerous and possibly subversive issues' (Hampton 31) this play represents a good field to analyse Lawrence's discourse on public institutions. Like Linda Ruth Williams says, 'all of Lawrence's work should be properly seen as a kind of fusion between the autobiographical, the philosophical and the fictive' (1993:61). Lawrence stars his theatrical life by approaching naturalistic theatre despite the fact that he does not agree with many of its principles. The presentation of social blots and degenerated environments of repulsion and misery are of special interest for naturalists. What Lawrence does is to start to embody the crises of immediate relationships by emphasizing dialect and family, both minutely reproduced in order to frame them within the slice of life drama of an ordinary situation

\section{Bibliography}

Becket, F. (2002) The Complete Guide to D. H. Lawrence. London: Routledge Benyon, Richard (1997). Icon Critical Guides. The Rainbow. Women in Love Cambridge: Icon Books.

Fernihough, Anne (2001). The Cambridge Companion to D. H. Lawerence. Cambride: CUP

Foucault, M (2002). El orden del discurso. Barcelona: Tusquets editores

'Good and Dirty'. The Guardian, September 112002

Guy Josephine (1996). The Victorian Social-Problem Novel. London: Macmillan Hampton, C (1990). The Ideology of the Text. Philadelphia: Open University Press Holderness, G. (1976). Who is Who in D. H. Lawrence. London: Elm Tree Books Hynes, S (1968). The Edwardian Turn of Mind. Princeton: Princeton University Press. Lawrence, D. H. Three Plays. Harmondsworth: Penguin Books

Sagar, K. (1982). D. H. Lawrence Handbook. Manchester: Manchester University Press.

Selden, R.; Widdowdson and Brooker (2001). La teoría literaria contemporanea. Barcelona: Editorial Ariel.

Trussler: S (2000) British Theatre. Cambridge: CUP

Williams, L. R. (1993) Sex in the Head. Visions of Femininity and Film in D. H. Lawrence. Hemel Hempstead: Harvester Wheatsheaf

Worthen, J. (1991). D. H. Lawrence: The Early Years 1885-1912. Cambridge. CUP 